\title{
The Aesthetics of Change: Exploring Post-Communist Spaces
}

\author{
ANCA PUSCA*
}

This article explores the relationship between material change and social change under a proposed theory of aesthetics of change. Suggesting a particular understanding of the aesthetic as concerned with feeling and perception, as opposed to artistic representation, the article explores different ways in which practices of seeing, walking and engaging with the material environment significantly affect our experience of social change. Borrowing from Walter Benjamin's notion of the flaneur and his idea of history as directly embedded into space and the material environment, the article explores the way in which two different forms of visual and spatial manipulations-the Painting Tirana Project, and the Czech Dream Documentary - significantly affect the way in which the post-communist transition was negotiated in Tirana, Albania and Prague, Czech Republic, respectively.

I resided as a mollusk resides in its shell in the $19^{\text {th }}$ century, which now lies hollow before me like an empty shell.

I press it against my ear. ${ }^{1}$

—Walter Benjamin

Human life is largely constituted by Things

and also deposited in Things

as in the peculiar geological layers

that let us observe the changes in age,

taste, attachments, and passions. ${ }^{2}$

-Mikhail Epshtein

\section{Introduction}

It is not coincidental that the rise and fall of different regimes and ideologies is most often marked by the material construction or destruction of symbolic buildings, statues, walls, constitutions or flags. This material does not just stand for

\footnotetext{
*I would like to thank Thomas Diez, Cerwyn Moore, Matt Davies and my anonymous reviewers for their excellent comments and questions.

1. Benjamin as quoted in Roland Kany, "Particularism in the Work of Walter Benjamin", Criticism Vol. 32, No. 3 (1990), p. 334.

2. Mikhail Epshtein, "Things and Words: Towards a Lyrical Museum", in Alla Efimova and Lev Manovich (eds),Tekstura (Chicago: University of Chicago Press, 1993), p. 153.
} 
marking particular political, economic or historical illusions and disillusions, but represents in itself a reflection of historical time and social change. The idea of change is thus inextricably related to the material world, whereby the material is used to support, confirm, justify and legitimate change. With any process of radical social and political change, there is an expectation that this change will be positively and significantly reflected in the material horizon. The relationship between social change and material change is often mediated through the visualand the visual horizon of particular communities.

Changes in this visual horizon are framed both through the larger discourse of social change and transition, as well as through particular ways of engaging with material change. These changes and framing processes can be captured in a larger theory of aesthetics of change that can be used to complement current analyses of post-communist transitions. By looking at how people read change into the surrounding environment, the proposed theory of aesthetics of change seeks to turn our attention towards a largely untapped resource within international relations-material space- as an essential tool of political communication across the public, private and political spheres. This "silent" (non-spoken) and non-textual communication relies on the visual and the material to convey and absorb expectations, frustrations and manipulations as related to the larger process of (radical) social change. Reading this silent, non-textual communication requires an understanding of the act of seeing-individual as well as collective-as related to a particular time and space dimension, as well as the implications of different practices of representation and manipulation of seeing through public visual statements, film and publicity.

While the idea of aesthetics is certainly not new to the study of politics and international relations, this article proposes a spatial as opposed to a textual or representational approach to aesthetics, ${ }^{3}$ whereby the focus is on the direct experience of seeing, the material space and the practice of walking or flanerie as a particular way of experiencing spaces of change or transition. A spatial turn within aesthetic studies in international relations provides us with an opportunity potentially to reconcile the perceived division between the mimetic and the allegorical or the artistic, by arguing that the two are in fact intrinsically connected in the spatial and material environment. ${ }^{4}$ This reconciliation is, however, only possible within a particular understanding of the aesthetic as not associated with the beautiful or even to a particular philosophy of art, but rather with the notion of perception and the emotions connected to perception. This definition is closer to the initial Greek meaning of the word aesthesis, that is, feeling or perception. ${ }^{5}$ Thus, an aesthetics of change is both a feeling as well as perception of change.

Both the Frankfurt School debates on the role of the aesthetic in politics ${ }^{6}$ and the more recent aesthetic turn in international relations ${ }^{7}$ approach the aesthetic as either mimetic or allegorical, where the two modes are separated by distinctions

3. For an interesting hermeneutical approach to aesthetics see: Cerwyn Moore, "Reading the Hermeneutics of Violence: the Literary Turn and Czechnya", Global Society, Vol. 20, No. 2 (2006).

4. The existence of such a division was argued in: Roland Bleiker, "The Aesthetic Turn in International Political Theory", Millennium: Journal of International Studies, Vol. 30, No. 3 (2001).

5. Jacques Aumont, The Image, trans. Claire Pajackowska (London: British Film Institute Press, 1997), p. 197.

6. Theodor Adorno et al., Aesthetics and Politics (London: Verso, 1977).

7. Bleiker, "The Aesthetic Turn in International Political Theory", op. cit.; Roland Bleiker, "Learning from Art: A Reply to Holden's 'World Literature and World Politics", Global Society, Vol. 17, No. 4 (2003). 
between forms of representation and what is actually represented. The favouring of either the mimetic (the Frankfurt School as represented by Lukacs, Horkheimer and to a certain extent Adorno) or the allegorical (the Frankfurt School as represented by Brecht, and the aesthetic turn as represented by Bleiker) is, to a certain extent, justified by which one stands "truer" to the nature of "reality" and how it should be examined. Associating the aesthetic with different forms of representation alone-whether it be poetry, painting or film and photography-misses the connection between "reality" and "interpretation". One way to re-establish that connection, as initially suggested by Walter Benjamin, ${ }^{8}$ and later also developed by film theorists such as Kracauer ${ }^{9}$ and Elsaesser ${ }^{10}$ is to focus on the connection between the act of seeing and the material itself as the initial step in any representational process.

The interest in an aesthetics of change lies not only in questions of how social change has been represented, but more importantly, how the experience of social change has been affected by these representations and changes in the material environment. Building on Walter Benjamin's theory of change and history as directly related to transformations in the material environment, this article proposes to explore different practices through which social change is read into the material environment and vice versa. With the aim of normalising as well as questioning the experience of change, these practices combine physical manipulations of the environment as well as visual manipulations of the way in which that environment is represented. Borrowing Walter Benjamin's notion of the flaneur, the article identifies the "seer" as the collectivity directly experiencing the change or transition, the space of change as post-communist Europe, and the material transformation as transformations (whether temporary or permanent in nature) in the build environment of post-communist Europe.

The article first examines the nature of material change in post-communist Europe and the relationship between "temporary" and "permanent" structures. It then explores the notion of the flaneur as key to understanding the role of the visual and the impact of new technologies of seeing on the experience of change. Thirdly, it provides two brief explorations of different types of material and visual manipulations that have significantly changed the experience of transition in Tirana and Prague. The first of these explorations focuses on the Painting Tirana Project, initiated by Tirana's mayor in 2000, while the second focuses on the successful Czech Dream Documentary directed by Vit Klusak and Filip Remunda.

\section{The Fragility of the Permanent and the Stability of the Temporary}

The collapse of the communist regimes in Central and Eastern Europe was marked by the literal collapse of structures and bodies previously perceived as indestructible - the Berlin Wall, the bringing to trial and shooting of dictators such as Ceausescu, the tearing down of "communist" statues and the closing

8. Walter Benjamin, Illuminations, ed. Hannah Arendt, trans. Harry Zohn (New York: Schocken Books, 1968), Walter Benjamin, Reflections, ed. Peter Demetz, trans. Edmund Jephcott (New York: Schocken Books, 1978).

9. Siegfried Kracauer, Theory of Film: The Redemption of Physical Reality (New York: Oxford University Press, 1965).

10. Thomas Elsaesser, "Cinema - the Irresponsible Signifier or 'the Gamble with History': Film Theory or Cinema Theory", New German Critique 40, Special Issue on Weimar Film Theory (1987). 
down of former industrial giants. Destruction, rather than construction, seemed to prevail, clearing up space for new ways of inscribing the material with fresh colours, new memorials and a different kind of hope. The process of construction, often inhibited by lack of funds, relied mainly on renovation and decorative work as well as a series of temporary structures such as kiosks and open markets. Thus, much of the initial material change that occurred in post-communist Europe focused on superficial change such as the painting of facades, the replacing of old communist slogans with new publicity panels, and the appearance of stores at the street level of most buildings as well as new brands and fashion.

The old squares of Prague, Budapest or Warsaw did not incur any major structural change, yet they did look and feel different. The creation of restaurant patios opened up the space for a different kind of gazing; the establishment of large shopping areas, the neon signs, the memorabilia stands, the casinos, the new memorials, created a colourful, vibrant atmosphere that led journalists, tourists and even locals to conclude that radical social change had indeed occurred. Compared to old images taken during the 1970s or 1980s demonstrations, the Wenceslas square in Prague seems unrecognisable today, and yet the structures are almost identical. Assuming that social change can indeed be read into changes in the material environment, one cannot help but wonder whether the assumed radical social change read in the otherwise superficial material change should not be reconsidered.

The expectation that social change should necessarily be followed by visible and significant material change in the environment surrounding us is quite strong in post-communist Europe. While this should not be surprising, given that, as Susan Buck-Morss ${ }^{11}$ argues, the communist social utopia was largely supported through visual and material reminders of progress and well-being, what is surprising is the relatively little and often temporary effort that is required to fulfil or appease it. A glance away from the main city squares reveals the prevalence of cheap construction materials, fake facades that hide destruction and collapse, unfinished projects and an overwhelming number of temporary structures, such as kiosks and open markets that serve, in turn, to promote different types of temporary facades, such as fake brand electronics and fashion, used cars and pirated music. This superficial material change, however, should not necessarily be dismissed as nothing but a transition phase soon to be replaced by more permanent structures.

These temporary facades and structures, such as the kiosk and the open market, do in fact play an essential role in negotiating people's understanding of change. On the one hand, they provide everyone with material proof that things are indeed changing, and on the other, they create an atmosphere of "dress rehearsal" whereby both spaces and people are covered in temporary facades that mimic and perform change as if the process of change had actually been completed. Much like the transition from communism to capitalism, the transition from temporary facades to an actual change in structures, from fake brands to real brands, from dilapidated buildings to strip malls, marks, according to some, a normal step in a so-called natural progression towards a more "westernised" and "European" post-communist Europe. ${ }^{12}$ In this progression, the temporary structure

11. Susan Buck-Morss, Dreamworld and Catastrophe: The Passing of Mass Utopia in East and West (Cambridge, MA: MIT Press, 2000).

12. Karina Kreja, "Spatial Imprints of Urban Consumption: Large Scale Retail Development in Warsaw", in Sasha Tsenkova and Nedovic-Budic-Zorica (eds), The Urban Mosaic of Post-Socialist Europe: Space, Institutions and Policy (Heidelberg: Physica-Verlag, 2006). 
appears as a much-needed appeasement, yet one that everyone wishes away as soon as it is no longer necessary.

Architects such as Srdjan Jovanovic Weiss would disagree. He describes temporary architecture as "an exception to the stable and obedient arrangement of space" ${ }^{\prime 13}$ one that also implies an inherent "accepting [of] a deadline of its own expiration, the end of its own incapability to be stable". ${ }^{14}$ He notes, however, an important characteristic of temporary architecture in post-communist Europe, in his case, the city of Belgrade in that it fails to accept its expiration and thus creates an environment that is based on a series of "temporary evasions". The superficial facades, the improvised bars, the party streets that only look good at night under colourful lights, thus become a permanent fixture of the city, one that it does not necessarily seek to change. ${ }^{15}$ These temporary "permanent" structures serve not only to question the idea of change as following a gradual progression from the unstable to the stable (with its material implications included) but also act as a claim to a unique identity that captures the "transition experience" in its very look and celebrates the ability to "normalise" otherwise shocking conditions through the acceptance of the temporary as permanent. ${ }^{16}$

This process of normalisation of the temporary is mediated by particular routines and the association of temporary spaces-such as improvised neighbourhood bars or kiosks-with the struggle for survival. In these instances, the temporary space itself becomes a witness to the economic struggle of transition-inflation, unemployment, poverty-as well as a faithful friend that does not boast, but remains simple, unsophisticated, cheap and to the point. The night shift worker who stops to drink a quick shot of vodka or buy some bread at the neighbourhood kiosk finds comfort in this space, perhaps because, in its very makeshift, rusty way, it stays true to the larger social transformation taking place and does not seek to hide behind a mask of pretence. ${ }^{17}$

Through their very presence at the kiosk, and its inclusion in their daily routine, the workers make a powerful statement about the way in which they experience the transition. This statement, however, becomes quickly invisible when one tends to look for written or verbal confirmation, and is often confused with a state of apathy or even worse, a state of idleness. The impulse to erase this idleness through an act of spatial erasure - the destruction of these makeshift constructions and kiosks-also erases along with it the very public presence of the individuals who populate these spaces, for they can no longer afford to be anywhere other than their homes, and sometimes not even there. ${ }^{18}$

13. Srdjan Jovanovic Weiss, Evasion of Temporality, Holcim Forum for Sustainable Construction, 2007, 〈http://www.holcimfoundation.org/T463/TemporaryUrbanism.htm〉 (accessed 9 November 2007).

14. Ibid. [cited]. p. 333.

15. Ibid. [cited]. p. 334.

16. For a more detailed discussion of the implications of shock in transition societies, please see: Anca Pusca, "Shock, Therapy and Postcommunist Transitions," Alternatives, Vol. 32, Issue 3 (2007).

17. Opened by neighbours and friends often forced into entrepreneurship by lack of other job opportunities, these bars and neighbourhood kiosks maintain an important sense of community and simplicity, where people can gather, drink and shop at reasonable prices as well as exchange favours and learn about new opportunities. These observations are mainly based on ethnographic work in Timisoara, Romania.

18. These "temporary" structures, because of their unkempt aspect and association with drunkenness and wastefulness, have often been seen as shameful spots on the otherwise positively changing 
The temporary, along with different practices that mask it as non-temporary, thus needs to be tracked and studied as an important part of the transition experience. Before moving on to an examination of the different ways in which temporary facades have had a significant impact in the life of two different post-communist cities, Tirana and Prague, it is important to understand the role of the "seer", the flaneur, and the different mechanisms and technologies of seeing in the process of engagement with the material environment and in particular with temporary structures. These different technologies of seeing open up new possibilities of manipulation, legitimation, representation and politicisation of spaces that would otherwise remain mundane and indifferent.

\section{The Flaneur, Visuality and New Technologies of Seeing}

The concept of the flaneur can be traced back to Baudelaire's poetics ${ }^{19}$ where it is associated with a particular way of experiencing the city, whereby one strolls aimlessly in order to observe otherwise insignificant details and draw upon them for inspiration and insights into the nature of society at that particular moment. Walter Benjamin was particularly inspired by the concept as well as the technique of strolling, using them as a way to explore nineteenth-century Naples, Berlin, Paris, Marseilles and Moscow, and to develop a new understanding of history as directly related to images and the material. ${ }^{20}$ For Benjamin, the flaneur was associated with those at the margins of society-the homeless, the whore, the sandwich-man, the collector. ${ }^{21}$ What they all shared was a privileged way of seeing the city from angles inaccessible to anyone else-the city at night, the back alleys, the abandoned buildings, the antiques that could only be seen as interesting by collectors. The flaneur thus embodied a way of seeing as well as a particular way of framing what one sees.

The flaneur's association with the act of walking is equally important to the act of seeing. Modern theorists of visuality, such as Aumont argue that "the idea of space is fundamentally linked to the body and its movement". ${ }^{22}$ The bodily movement combines both elements of space and time. It is through the body in movement that we are exposed to different frames of seeing, as well as the passing of time. The latter is directly marked by synchronies and asynchronies in the material and spatial change as noted by our sight. The notion of change, and

face of the city. Those located close to or even within the city centre and city parks were seen as particularly threatening due to their high visibility and seedy "membership", leading local governments to campaign heavily for their destruction. President Basescu of Romania led a very successful "cleaning-up" campaign in Bucharest, demolishing thousands of structures in the city centre and erasing along with them, the visibility of poverty, disillusionment and despair under the fighting corruption banner (the claim was that many of the kiosks in the city centre were illegally run by a number of corrupt nouveaux riches). Although the corruption charges are likely to have been right, the move contributed to the further marginalisation of those who did not fit the positive image of transition-the unemployed, the few remaining factory workers, the homeless and even the seedy entrepreneur.

19. Charles Baudelaire, Les Fleurs Du Mal (Boston, MA: David R. Godine, 1985).

20. Susan Buck-Morss, The Origin of Negative Dialectics: Theodor W. Adorno, Walter Benjamin, and the Frankfurt Institute (New York: The Free Press, 1977).

21. Walter Benjamin, One-Way Street, trans. Edmund Jephcott and Kingsley Shorter (Frankfurt: Suhrkamp Verlag Press, 1970).

22. Aumont, The Image, op. cit., p. 20. 
the passing of time, is thus directly connected to our ability to see change marked in space and our material surroundings. ${ }^{23}$ Our patterns of walking are thus essential determinants of what we see as well as the way in which we interpret what we see. Walking, as an everyday practice-as opposed to marching or a street gathering and demonstrating - can also be seen as a political practice that determines our frames of seeing as well as our conceptualisation and interpretation of space.

Social theorists such as De Certeau, ${ }^{24}$ Lefebre $^{25}$ and Guy Debord ${ }^{26}$ developed a particular interest in analysing the practice of walking as essential to our social and political awareness. To the extent that all politics and historical transformation is marked directly into space, the practice of walking is essential to uncovering those markings. In his writings, and more importantly his political practice, Guy Debord-as the leader of the Situationalist movement and the main inspiration for today's psycho-geographers ${ }^{27}$ — continued to emphasise something that Benjamin had noted before namely, that maintaining certain patterns of walking served to normalise change, by masking the shock of change through the maintenance of similar frames of seeing. This is why the literal breaking of walking patterns was an essential practice of the Situationalists, not as an act of rebellion, but rather an act of re-framing that would allow otherwise marginal or different frames to be adopted as well.

The more recent work of Iain Sinclair ${ }^{28}$ shows how this breaking of walking patterns can serve as a way to break down not only visual frames but also temporal frames. In his explorations of London, Sinclair writes about his own experience of seeing as much more than the physical act of seeing and framing, but rather as an imaginative, creative process whereby the images recorded are immediately associated with other images, emotions, thoughts and recollections. By tracing changes in the meaning of different objects, buildings and sites throughout time-from churches, to statues, to neighbourhoods, shops and pubs-Sinclair uncovers a universe in which the "real" and "representation", objects and images, past and present have similar qualities, to a point where they become interchangeable. ${ }^{29}$ Physical space then becomes much more than what one can see. It becomes also something that one can recall or imagine. Walking thus exposes us to a series of different visual as well as temporal frames, breaking down space into a montage of material and visual as well as imaginary representations of that material.

23. The film Goodbye Lenin captures this very nicely through the metaphor of the mother who is protected from the shock of change through the preservation of the material environment that she inhabits. Brands, objects and newspapers are used to maintain that stability.

24. Michel de Certeau, "Walking the City", in The Practice of Everyday Life (Los Angeles: University of California Press, 1984).

25. Henri Lefebvre, Everyday Life in the Modern World (New York: Transaction Publishers, 1984).

26. Guy Debord, The Society of the Spectacle, trans. Donald Nicholson-Smith (New York: Zone Books, 1994).

27. See more on the Situationists in Alastair Bonnett, "The Nostalgias of Situationist Subversion", Theory, Culture E Society, Vol. 23, No. 5 (2006); Stefan Zweifel, Juri Steiner, and Heinz Stahlhut, In Girum Nocte Et Consumimur Igni - the Situationist International (1957-1972) (Zurich: JRP/Ringier, 2006).

28. Debord, op. cit.; Iain Sinclair, Downriver (London: Vintage, 1995); Iain Sinclair, Lights out for the Territory (London: Granta Books, 1997); Iain Sinclair, Lud Heat and Suicide Bridge (London: Vintage, 1995).

29. Ben Watson, Revolutionary Novelist or Revolting Nihilist?, 〈http://www.militantesthetix.co.uk/ critlit/SINCLAIR.htm〉 (accessed June 6 2007). 
New technologies of seeing, such as photography, film and "new media" have also played with this relationship between the representation and imagination of space. As Benjamin predicted, they have indeed changed our modes of perception, $^{30}$ and along with it the way in which we perceive or read the material environment surrounding us. Beyond providing new frames of seeing, many of these technologies have removed the need for the act of walking in the representation of space, serving to silence the continuing role that this act has on perceptions of change and expressions of the political in the physical environment. From media studies to the so-called "aesthetic turn", the fascination now lies with the question of "representation" as related to film, photography, images, and no longer with the direct act of seeing, unmediated by particular technologies.

Representation is, however, often not completely removed from the material environment. In fact, a majority of representational images-posters, publicity, paintings, photo exhibits-maintain a material quality and thus remain an important part of the surrounding material environment. Given the increase in reproduction mechanisms and techniques, ${ }^{31}$ these visual representations have the ability to radically alter the material environment with little time or financial outlay. They serve to manipulate easily experiences of change, both by normalising the temporary and questioning the permanent, as the two short explorations of Tirana and Prague will attempt to show.

Walking and seeing are thus intrinsically connected, particularly when it comes to experiencing social change as inscribed in the material environment. The concept of the flaneur brings our attention to the impact of following or breaking particular patterns of walking and seeing. New technologies of seeing, when examined in relation to the practice of flanerie, show the extent to which different forms of representation have come significantly to alter the material environment, by confusing the temporary and the permanent, and thus blurring expectations that radical social change can only be read in radical material change.

By taking the notion of the flaneur seriously and engaging with the relationship between walking and seeing as a new possible methodology for examining the socalled aesthetics of change, the two case studies examined below seek to offer one possible way of employing such a methodology. Acknowledging the subjectivity of the flaneur experience and the impossibility of recognising everyone's field of vision and internalisation of change through the act of walking and seeing, these two case studies seek to offer nonetheless a possible entry point into a different kind of empirical work that openly acknowledges not just what is being seen, but also who sees, what and how. Relying on Benjamin's conviction that images are not only material fragments but also thought-fragments that capture within themselves a miniaturised image or idea of the world, the case studies will seek to offer an alternative view of the politicisation of the transition experience that seeks not so much to refute but rather to complement the already rich, albeit rather homogeneous, literature on post-communist transitions.

The Painting Tirana Project and the Czech Dream Documentary thus serve to showcase different ways in which visual representations have radically altered the material environment, triggering an increasing awareness of space, and its

30. Benjamin, Illuminations, op. cit., p. 222.

31. Walter Benjamin, "The Work of Art in the Age of Mechanical Reproduction", in Illuminations, op. cit. 
role as a potential political mediator. Following Jacques Rancière's argument that politics lies within the (re)configuration of space as the framing of a specific sphere of experience, ${ }^{32}$ the two case studies suggest that it is precisely within such gestures of manipulation that possibilities of political action are created or reconfigured. The manipulation of space and the visual experience itself thus serve to challenge previous expectations and, in some cases, act as a form of critical engagement with both the material motivations underpinning spatial change as well as the visual technologies that sustain it.

\section{A Flaneur in Tirana}

Initiated by its artist mayor, Edi Rama, almost immediately after his election to City Hall in 2000, the Painting Tirana project involved the revamping of the old communist flats of the capital of Albania through bright colours that would change both the look of the city as well as inspire its citizens with vivacity, a fresh new start and a brighter horizon. The project was part of a larger movement towards the "city's renaissance" that also involved the refurbishment of abandoned parks and river banks turned into refuse dumps, the repairing of roads and a lighting project that sought to revive the city at night. The results are showcased on the main website of the municipality of Tirana in a before and after photo gallery with the new facades, the lighting project, the refurbished parks and the newly paved streets bringing a ravaged city back to life. ${ }^{33}$ The lively brushstrokes of green, red, purple, orange, yellow and blue, the squared and rounded shapes on buildings, the patched, quilted look of facades, is both pleasing and intriguing to the eye. From a city in ruin, Tirana has turned into a city of colour.

The Painting Tirana project was a bold statement not only for a collapsed city, but also for Albania, a country ranked as the poorest in Europe, struggling with the effects of the Yugoslav wars, the incoming Kosovo refugees, and its own emigration problem. ${ }^{34}$ The image of thousands of illegal Albanian immigrants piled up in boats heading for the Italian coast was replaced by one of a lively, revived city that for the first time in decades managed to attract tourists and its own elites that had moved abroad. The new look of the city managed to shift both the mood and attitude of the population, as well as the political debate on to the spatial cityscape arena, opening the door to a new kind of communication between, in this case, the local government and the inhabitants of Tirana. By fulfilling people's expectations that social change should be reflected (positively) in the surrounding material environment, Edi Rama, mayor of Tirana, gave the citizens of Tirana a reason to believe, a material proof, that although superficial, was clearly visible and held the promise of more. ${ }^{35}$

32. Jacques Rancière, "From Politics to Aesthetics?" Paragraph Vol. 28, No. 1 (2005).

33. See official site of the municipality of Tirana: $\langle$ http://www.tirana.gov.al/?cid=2,10,23 $\rangle$ (accessed 7 June 2007).

34. For a more detailed examination of the wider context of the Albanian post-communist transition see: Clarissa de Waal, Albania Today: A Portrait of Post-Communist Turbulence (London: I.B. Tauris Press, 2005); Douglas Saltmarshe, Identity in a Post-Communist Balkan State (London: Ashgate Publishing, 2001).

35. One of the biggest challenges to the post-communist transitions has been the ability to spread and make visible the positive "material" transformations beyond the city centres. By recognising the importance of making change visible everywhere in a more equal as well as friendly, incremental 
Financed with no more than $\$ 67$ million, $^{36}$ the project instilled hope in an otherwise largely apathetic population, resulting in a surprising vote that made Edi Rama the winner of the World Mayor 2004 contest. $^{37}$ The comments posted by his voters showed that this was an overwhelmingly positive response to his "city renaissance" policies, and particularly the Painting Tirana project. Voters saw hope, stability, identity and pride in him and his projects. They saw the ability to fulfil promises, and thus to rehabilitate the prevalent negative image of politics and politicians. ${ }^{38}$ They also saw Edi Rama as someone other than a typical politician, an artist who governed under no ideological or party doctrine, but rather in the belief that society needed to look and feel different in order to embrace the change brought about by the fall of communism:

Edi Rama is something else altogether from your average politician, in fact the reason he is so successful is that he is NOT one. He represents a new generation of Albanians, one that has no more time to waste, and no doctrines to experiment with, no 'great fathers' to listen to and follow. I find him arrogant, at times unpleasant, I have never felt he can give an interview, but above all I can see the city I love, and was born in, and I know how much he had to do with the way it looks and feels these days. Edi Rama, thank you! ${ }^{39}$

Even his enemies could not deny the important role that he has played in changing the face of the city for the better. Despite being blamed for his arrogance and his tendency to turn the city into his own canvas, ${ }^{40}$ Edi Rama has managed to achieve in good part his initially stated goal: "My real project is to try to resuscitate hope, so that people will start looking on their country not as a transfer station, but as a place where they might want to live." ${ }^{41}$ The uniqueness of his approach lies not only in his urban revival strategies, something that urban planning policies and architects everywhere have long upheld as positive and essential, but rather in his prioritising of these strategies above the usual employment and economic revival promises. His genius was to recognise the importance of the shortterm and not just the long-term, the need to change the "look and the feel" of the city immediately, even if this meant encouraging superficial change through a coat of paint.

By changing the way in which people look at their own city, by drawing their attention towards the possibility of change, by giving them a glimpse of what

manner, Edi Rama embraced the superficiality and temporary nature of colours as an efficient way of signalling change as an interactive process in which everyone is an equally important participant.

36. Vivienne Walt, "A Mayoral Makeover", Time, 2 October 2005.

37. See featured article on the World Mayor webpage: 〈http://www.worldmayor.com/worldmayor_ 2004/comments_rama.html $>$ (accessed 6 June 2007).

38. While the on-line voters are certainly not representative of the entire population of Tirana, they do show both the extent to which Edi Rama has managed to mobilise a majority of Tirana's inhabitants (enough people needed to vote in order to make him World Mayor) as well as the positive impact that he has had on widespread attitudes towards the city at home as well as abroad.

39. Quoted from the City Mayor's site:〈http://www.citymayors.com/gratis/city_mayors.html〉 (accessed 6 June 2007).

40. Walt, op. cit.

41. Colin Woodward, "Trendy Tirana? Mayor Invigorates a Backwater Capital", The Christian Science Monitor, 23 March 2005. 
their city could look like one day and allowing Albanian emigrants to take pride in it even from abroad, the artist-turned-politician tricked the "natural" aesthetic of change, manipulated the look and feel of the change, reframed the horizons of the visual and literally moved the city into a new temporality-the potential longterm future. All this was achieved through a mere creative repainting of facades. The structures behind them are still corroded and slowly collapsing, the pipes and infrastructure are still old, the over-population problem is still there and yet things "look and feel" different, and positively so.

In Prague, Budapest or Warsaw, only the old towns were repainted; in Tirana, the look of the entire city was changed. Edi Rama did not shy away from painting over old communist flats or meagre-looking three storey buildings at the outskirts of town. The aim was to change the aesthetic experience of the everyday flaneur walking to work, the local supermarket or heading back home, and not just the tourist, the businessman or the investor who inhabits the city centre. Change needed to be felt in a uniform fashion, equally accessible and with similar transformative possibilities. The colours are not just paint on a canvas, an artefact, a visual trick, but rather an organic part of the material environment, a new visual frame through which otherwise little-changed structures can be perceived differently. As Rama himself explains, the colours are means to replace the old, rotting, organs of the city - they may appear superficial, an easily erased makeup, but they constitute a significant intervention. ${ }^{42}$

The colours have significantly changed the walking/flanerie experience of the everyday inhabitant of Tirana. ${ }^{43}$ As Edi Rama himself notes, "there is perhaps no other city in Europe, be it the richest, where people discuss so passionately and collectively about colors. The hottest discussion in the coffee bars, in homes, in the streets was what are the colors doing to us". ${ }^{44}$ The photographs of Tirana walk us through a city that is definitely changing. The colours add contrast, bringing out the new air-conditioners, double-glazed windows and satellite dishes, the publicity banners, shops and neighbourhood bars. They help to confirm, silently, yet powerfully, that things are indeed changing, and that the myriad of promises after the fall of communism will not all drown in boats heading for the Italian coast.

Anri Sala, another Albanian artist and former roommate of Edi Rama in Paris, put together a video montage entitled Dammi I Colori, showcasing the colours of Tirana and its mayor in a drive-by interview that juxtaposes Tirana's freshlypainted buildings with Rama's presentation of the project. The video montage was shown at the TATE London, as well as several well-known galleries in Paris, Hamburg, New York and Chicago, and has appeared in two Venice Biennales. ${ }^{45}$ The video sought to (re)present the changes that the Tirana flaneurs were experiencing on an everyday basis, and thus juxtaposed images seen

42. Quoted in: Jane Kramer, "Painting the Town", New Yorker, 27 June 2005.

43. Interviews cited by both local and international media, on-line testimonies as well as email communication with inhabitants of Tirana support this claim. While the flanerie experience of each individual is certainly subjective and difficult to portray, the overall examination of the change in visual horizon suggests that the collective flanerie of the everyday inhabitant of Tirana has generally taken a more positive turn.

44. Quoted in a 2007 interview by Anri Sala, sent via email, personal communication.

45. For more information see: 〈http://www.artnet.com/Magazine/reviews/douglas/douglas11-404.asp > 
through the movement of the car, with verbal commentary, reproducing both the relationship between the body in movement and space as well as the visual and the verbal narrative. It sought to present Albania, and Tirana in particular, as a state of mind and a particular experience of space that can only be reproduced visually and materially-as directly opposed to the textual and verbal narratives that have always dominated "discourses" of change.

By exposing the relationship between social and material change through the careful manipulation of the aesthetics of change, whether willingly so or not, Edi Rama is also exposing the manipulative power of projects such as his, as well as other mechanisms of "painting" the city, perhaps more common in the general cityscape of post-communist Europe in the publicity panels, the colourful posters, the new brands and the fashion stores. The quick transformation of the Tirana cityscape also challenges the process of normalisation of change through the acceptance of often insignificant and temporary change as radical change. It underlines how easy it frequently is to misread "progress" in the material environment, and to represent it, visually, in places where only its promise exists. It challenges the nature of our expectations that change should be immediately visible and more importantly, that it should follow a particular model of "progressive" transformation. ${ }^{46}$

More importantly, however, it opens a new space of analysis in which politics becomes embedded in the transformation of the material environment, the silent engagement with that environment, and the possibilities that new ways of seeing old spaces open up. While the popularity of Edi Rama was indeed expressed through a voting process, his promises were not made standing on a platform addressing the crowd, but rather on the city as a canvas, on the buildings of Tirana, on that blue, or red or yellow patch of paint that reframed the way in which people looked at collapsing buildings, the corner of the street, the neighbourhood shop or the park by the river. What became visible was not only the "new" but what was already there-the decrepit, the old, the temporary, suddenly turned endearing and less threatening in its failure to meet expectations.

One subjective reading of the spatial transformation of Tirana, while acknowledging the impossibility of recognising each and every flaneur of Tirana, relies on deductions concerning what the effects of collective flanerie might be. In the case of Tirana the appeasement of the need for the senses to feel something different led to an acceptance of the present for what it was. The spectacle of colours resulted in an unexpected catharsis that suddenly implicated everyone in the process of change. The city appeared not just as a stage on which politicians could act, but rather a space in which collective practices of seeing and walking became visible gestures of approval or disapproval, of collaboration or rejection, of social and political communication. Moreover, by swiftly moving the temporality of the city into the future, the colours not only put the past behind, transforming communism into an allegorical time, a once-upon-a-time, but also helped to temper expectations that social change should necessarily translate into material

46. This expectation was largely supported by a "discourse" of a return to "Europe" that encouraged most post-communist states not only to dream of European Union membership but also to imagine themselves as a "physical" part of the West. The transition was thus popularly assessed by the extent to which one adopted the "look" of the West. Thus, the transition will be over when postcommunist cities "look and feel" like Frankfurt, Paris or London. 
change, and that the visibility of some material change is necessarily a sign of "progress".

The Painting Tirana project demonstrates the extent to which a simple act of repainting can transform an entire city and its inhabitants, by using the temporary, freshly painted facades both as a material promise that change is on the way, as well as a manner of reframing the visual experience of everyday flaneurs and engaging them in the larger political transformation of the country. Space thus becomes much more than a canvas on which history and change leave their trace, but also a board on which promises can be pinned, an arena in which the visual replaces verbal and written communication.

\section{Three Thousand Flaneurs in Prague}

North from Tirana lies another post-communist city, Prague, a city that has been praised for its outstanding economic performance as well as for its beauty and ability to attract tourists from all over the world. Prague has experienced a different type of aesthetics of change. Much more successful in its ability to replicate the "western" look, and to distinguish itself as a favourite capital of Europe, the Prague cityscape is struggling with the appearance of radically new structures such as hypermarkets and malls that in turn pose new dilemmas to the process of aesthetic change. ${ }^{47}$ While facades in the centre of Prague have also been painted over, there has been no equivalent to the Painting Tirana project. Another project however has revolutionised the way in which the local inhabitants of Prague visualise and frame the material changes taking place in their city-the Czech Dream documentary.

Directed by two young Czech film-makers-Vít Klusák and Filip Remundaas their final project for their film school, the documentary tracks the publicity and opening campaign for a hypermarket, symbolically named Czech Dream, a hypermarket that would never be built outside of the imagination of the two film makers, but which managed, notwithstanding, to attract over 3,000 people to its fictional opening. Claimed to be by far the largest publicity and consumer hoax the Czech Republic ever experienced, the documentary made waves in the film world, winning a number of different awards, both at home and abroad, from the student Oscars nomination by the Film Academy in Prague to the Golden Gate Award for Best Documentary Feature at the 2005 San Francisco International Film Festival and the Best Nonfiction Film Award at the Michael Moore Traverse City Film Festival. The Economist called it the funniest European film of the year and The New York Times called it the comedy of capitalism while the British Film Institute Sight and Sound magazine called it unclassifiable. $^{48}$

47. Often presented as a model city and country in the post-communist transitions literature, Prague and the Czech Republic appear as a miracle of capitalist transformation, along with Hungary and Poland. For a more detailed analysis of the implications of this "miracle discourse" as well as a wider analysis of the Czech context of post-communist change see: Elaine Susan Weiner, Market Dreams: Gender, Class and Capitalism in the Czech Republic (Ann Arbor, MI: University of Michigan Press, 2007); and Jiri Vecernik, Markets and People: The Czech Reform Experience in a Comparative Perspective (London: Avebury Publishers, 1997).

48. Vit Klusak and Filip Remunda, Czech Dream (Prague: Irena Kovarova/SchwarzSmith \& Taskovski Films, 2004), see〈http://www.ceskatelevize.cz/specialy/ceskysen/en〉. 
Inspired by theatre director Petr Lorenc, whose original idea was to advertise a fictional out-of-town hypermarket to trick people into going for a walk in the countryside, the film focuses on the extent to which images, brands and publicity can fool people into action: visiting a non-existent hypermarket and enjoying a beautiful day out in an open field with nothing but a wooden prop that stands as the façade for the so-called hypermarket. Celebrated as a critique of consumerism and the entire apparatus that supports it, the film however offers a multitude of stories: not just those intended by the two directors as the main actors, but also those brought forward by the 3000 or more people who showed up for the opening-and the city that they inhabit, Prague. The film is not so much a farce on capitalism, but a farce on the visual illusion of change and spaces where change can be experienced first hand-such as hypermarkets. ${ }^{49}$

The special television and radio spots, the 400 illuminated billboards, the 200,000 fliers, the advertising song, the website and the newspaper and magazine advertisements used to publicise the non-existent hypermarket all gave out mixed messages, from the "Don't Go, Don't Rush, Don't Spend" message on the billboards to the "It will be a nice big bash, and if you got no cash, get a loan and scream, I want to fulfill my dream!"50 message in the advertising jingle. The signs and posters that invaded the cityscape and visual-scape of Prague in the two weeks prior to the supposed opening of the hypermarket were meant to guide the consumer and flaneur towards one particular path-the Czech Dream hypermarket. Situated on the margins of town, the hypermarket lured its clients with unbelievable prices and promises of a much better life on the cheap.

Informed by the latest technology that helps to identify the colours, fonts, products, and prices that are most attractive to Prague customers, classified by gender, social standing and age, the publicity campaign, as followed throughout the documentary, seeks a precise manipulation of the vision of Pragueflaneurs, one that guarantees results and can be easily tracked and assessed. The framing is simple: we sell you your dream - the Czech Dream - the ability to own everything you ever wanted to own. A quick scan through the crowd that did turn out at the opening, reveals a not unexpected mix of people-the old, the poor, the deal hunters and the hopeful. Those who turned out believed in the "too good to be true prices" not only because the advertising was so good, but perhaps because they needed to, because those were the only prices that they could afford to pay.

Yet it is not the critique of capitalism aspect of the documentary that this case study would like to focus on, nor the meaning and inner-workings of the publicity campaign, but rather how this documentary and the visual tools employed to guide it, have helped to alter the way in which the changing material environment of Prague is to be perceived and interpreted. While the documentary, just like the publicity poster, is no doubt a representation, a visual tool as well as a visual technological manipulation, its props - the fake hypermarket façade, the paper on

49. The documentary is also a backhanded critique of some of the material motivations and interests underpinning spatial change in post-communist Europe. Most of these material motivations are supported not only by foreign investors seeking to provide a beautiful façade for their profit-making investments but also by the European Union structural and development funds, which seek to invest in long-term infrastructure that will help turn its new post-communist members into a booming market for EU products as well as cheap suppliers of goods, workers and creative potential.

50. Liese Spencer, "Reviews: Czech Dream", Sight and Sound, Vol. 15, No. 7 (2005). 
which the posters were printed and the walls on which they were placed-as well as its protagonists - the people who came and the hypermarket as a structure in general-were a part of the material environment of the city, and a part of the aesthetics of change as read into this material environment. With a message more precise than the colours of Tirana, the posters and the fake façade did, however, do much more than fool people into believing a hoax. They led not only to a fake hypermarket, but also to an abyss, to a breaking of patterns, or at least a questioning of hypermarkets as both a material as well as a symbolic place.

The appearance of hypermarkets has been, no doubt, celebrated as the triumph of change, the completion or near completion of the transition from communism to capitalism, as the material confirmation of years of political and economic promises and reform. ${ }^{51}$ If social change can indeed be read into the material environment, then hypermarkets would be the proof that significant change has taken place. As the Tesco manager interviewed in the documentary points out, things have changed from the time when he was a little boy, standing in a long line for bananas-a sparse commodity in communist times-feeling humiliated by the Japanese tourists filming him. For he now makes a good living, and has access to any goods that his heart desires, right there, in his store. Yet the Czech obsession with hypermarkets, as noted by the two documentary directors, may not be entirely healthy. In a 2004 interview, Klusak and Remunda explained why they chose to focus their documentary on hypermarkets:

In the course of a mere five years, foreign investors built 126 of them. In Holland, a country the same size as the Czech Republic, it took them quarter of a century. The Czechs started shopping in these hypermarkets more than people in the other post-socialist countries, and the new edition of the Czech dictionary of neologisms features words like hypermarketománie-a pathological addiction to shopping in hypermarkets, the worship of hypermarkets. ${ }^{52}$

The obsession is thus both material, as a result of the mushrooming of these structures to a point where they start to dominate the visual-scape of the city, as well as psychological, to a point of physical addiction. Yet the fetishism with commodities may not be the only explanation for this addiction. Hypermarkets could perhaps also be seen as a refuge, a confined, celebratory space, in which change for the better is indeed visible and radical, in which there are no contradictions and doubts, in which the material confirms loud and clearly that the transition has now been completed. The escape to hypermarkets is thus an escape from other visual horizons, the ones that do not so easily confirm the completion or success of the transition such as the grey suburban areas, the old blocks of flats, the dirty buses and streets, the begging homeless or the neo-Nazi marches.

Unlike the painted facades of Tirana, hypermarkets appear far from being superficial structures. They are the "real" thing, the sound, the permanent, the

51. See for example: Yaacov Garb and Tomasz Dybicz, "The Retail Revolution in Post-Socialist Central Europe and its Lessons," in Sasha Tsenkova and Nedovic-Budic-Zorica, The Urban Mosaic of Post-Socialist Europe: Space, Institutions and Policy, op. cit.

52. Collin O'Conner, Karlovy Vary Film Festival: Interview with Vit Klusák and Filip Remunda, 2004 [accessed November 26 2007]; available: 〈http://www.ceskatelevize.cz/specialy/ceskysen/en/ index.php?load=ofilmu_iw $\rangle$. 
non-temporary. And yet, perhaps the main point of the visual prop, the fake façade of the imaginary hypermarket, is to show that these permanent structures may not be as stable as they appear, and that an imaginary act of erasure opens up a space for roads that would otherwise not be taken, for destinations other than the market, for the beauty of non-inscribed, natural material. Looking for change in the material environment, trusting material change as confirmation of larger social change, is thus potentially deceiving not only in cases where superficial change is visually manipulated to appear as radical change, but also in cases where actual radical change appears more stable, permanent and positive than perhaps it is.

If the painted facades of Tirana are an appeasement of expectations of more radical change and yet to be fulfilled promises, the hypermarkets of Prague are an appeasement of the sometimes disappointing effect of the actual fulfilment of those promises. Both superficial façade colours and sound structures, such as malls and hypermarkets, ultimately have to rely on a certain element of suspension of disbelief. They are both props and decorations that seek to suggest a particular kind of change or development, which are supposed to be read in a distinct way. A mere change of lighting, or re-framing through new technologies of seeing such as photography or film, is enough to blur (or sometimes focus) the "text" on the walls.

As the repainted facades of Tirana served to open up public spaces and encourage a different kind of communication between the local government and its citizens, the hypermarkets of Prague had perhaps the opposite effect. They closed down exploratory spaces, guiding flaneurs towards an exact, enclosed target, in which the wonder-world of goods and diversity made everything seem possible. Just as in Vaclav Havel's Power of the Powerless, ${ }^{53}$ where the grocer places amongst the onions the sign "workers of the world unite", the publicity and fake hypermarket in the Czech Dream documentary also metaphorically and ironically place among the Prague cityscape the sign "consumers of the world unite".

The imaginary hypermarket in the Czech Dream documentary proposes a different kind of evasion of temporality, stepping back in time as opposed to leaping forwards, imagining a space where hypermarkets do not yet exist, where choices are made differently, spaces are explored unguided and patterns of flanerie do not follow a set path. This evasion serves to challenge the idea that change can be normalised through the achievement of a set final goal or the meeting of particular material expectations, thus challenging the idea that processes of change are necessarily based on a continuum whereby one moves from point $\mathrm{A}$ to point $\mathrm{B}$. The breaking of patterns of a particular flanerie (walking with the aim of reaching a particular space or goal) is also a symbolic breaking of the particular pattern or linearity of time.

\section{Conclusion}

This article has attempted to explore the relationship between material change and social change under a proposed theory of an aesthetics of change. Suggesting a definition of the aesthetic as concerned with feeling and perception, the article

53. Vaclav Havel, The Power of the Powerless: Citizens against the State in Central and Eastern Europe (New York: Palach Press, 1985). 
explored different ways in which practices of seeing, walking and engaging with the material environment significantly affect our experience of change. By turning to space as a key concept in our understanding of social change and political engagement, the article examined several post-communist spaces and offered a particular reading of how change has been written into those spaces.

Positioning itself within larger debates on the aesthetic turn in international relations, as well as debates on post-communist transitions and social change, the article hopes to open up new ways of exploring social and political change, through a focus on material change and the aesthetic experience involved in that change. By leaving the notion of the aesthetic open to a number of different ways of interacting with space-both through direct visual experiences as well as particular forms of representation such as photography, video montages and publicity - it has deliberately sought to distance itself from discussions of mass representation and instead, sought to understand how the individual, everyday flaneur, the "subject" of the transition, experiences change through his/her visual connection to the material. The material in this case has been mainly the build environment, as represented by a series of different "facades" - the painted facades of Tirana and the fake hypermarket facades on Prague.

By arguing that change cannot only be tracked in the "hardened" and the "permanent" but also in the "temporary" or the "seemingly temporary", the article proposed two different readings of two different facades through the Painting Tirana Project and the Czech Dream documentary. The facades presented two different ways of manipulating the built environment, even if only temporarily, in order to elicit a particular kind of "political" response whether it be political support in the case of Edi Rama or political protest in the case of Vít Klusák and Filip Remunda. Both manipulations, however, involved a recognition ofon the side of their authors-and an attempt to raise awareness of the intrinsic relationship between change and the material environment. In the case of the Painting Tirana Project, the awareness was a positive one, one in which the "old" was showcased as carrying a potentiality for the "new", while in the case of the Czech Dream documentary, the awareness was a negative one, in which the "new" was illustrated as constraining and potentially deceiving.

Suggesting that these manipulations are essential to the process of "normalisation" of change, and more importantly the "normalisation" of the "temporary" as acceptable not only in the short-run but also in the long-run, the article seeks to offer a different, perhaps more positive solution, to the post-communist conundrum of "permanent transition", whereby the transition is no longer perceived as a necessary movement from point A to point B. Rather, it is perceived as a particular way of negotiating expectations and coming to terms with the past, not only within a verbalised political discourse, but more importantly, within a larger visual, spatial and material discourse that directly engages both the individual and collective "subject" of the transition.

Recognising the act of seeing and walking as essential to our interaction with the material environment, and change as captured and manipulated within that material environment, the article briefly turns to the work of Walter Benjamin as a potential entry point for further explorations into the role of space within the aesthetic turn in international relations. The concept of the flaneur and the idea of an unmediated visuality create a new vantage point in which explorations of the international are not to be done from above or from a neutral outside 
position, but rather from within the subject itself. While recognising that modern forms of visuality and representation have significantly changed the visual horizon, in this case of so-called countries in transition, the article has tried to argue that, to the extent that many of these representations-posters, publicity panels, facades-become part of the material environment itself, the focus of a potential "aesthetics of change" should remain on the material itself as opposed to the implications of the different "forms of representation".

The "aesthetics of change" as represented by the material environment of Tirana and Prague thus suggest clearly that the post-communist transition is negotiated not only through economic reform packages, elections and integration into the European Union, but also through different forms of visual and spatial manipulations meant to legitimise and question individual and collective expectations as well as challenge ideas of the possibility of a swift "end of the transition" as marked by a fake sense of permanence in spatial structures imitating the "normality" of so-called "stable, non-transition" economies. 
Copyright of Global Society: Journal of Interdisciplinary International Relations is the property of Routledge and its content may not be copied or emailed to multiple sites or posted to a listserv without the copyright holder's express written permission. However, users may print, download, or email articles for individual use. 